\title{
A Chapter Closes: Bradford, Pollard and Lancaster-Jones
}

Miss Ditmas is director of ASLIB, and managing editor of the Journal of Documentation.

\section{"F} ifty Years of Documentation" 1 is the title of one of the papers by the late Dr. Samuel Clement Bradford, published in 1945. In a convenient phrase it describes that period of the history of bibliography during which "documentation" was born and came to maturity. It is, of course, true that documentation is far older than this catch phrase would suggest. If we define it as the aspect of bibliography in which the stress is laid most heavily on the development of aids to the active utilization of recorded knowledge, as opposed to custodianship, we realize that it has always been implicit in any scheme for the efficient arrangement of the materials of research. Nevertheless, in Europe at least, it can be claimed that the necessity for the development of documentation as a technique first received widespread recognition through the pioneer zeal of Paul Otlet and Henri La Fontaine, and with the foundation of the Office International de Bibliographie in Brussels in 1895 .

Professor Alan Faraday Campbell Pollard's paper, "The Disordered State of Bibliography and Indications of Its Effect upon Scientific and Technical Progress,"”2 gives many examples of scientific discoveries

\footnotetext{
1 Bradford, S. C. "Fifty Years of Documentation." Proceedings of the B.S.I.B., 7:43-51, 1945, Part 3 .

2 Pollard, A. F. C. "The Disordered State of Bibliography and Indications of Its Effect upon Scientific and Technical Progress." Proceedings of the B.S.I.B., $4: 41-52$, 1942, Part 3 .
}

which were not utilized because their first publication occurred in journals which escaped the attention of the specialists who could have appreciated their significance. But Pollard was echoing a theme which had been preached, in season and out, by Otlet and his friend and colleague, La Fontaine, since the close of the nineteenth century.

For Paul Otlet specialization was a snare unless it could be coordinated into a framework of universality. «Il réfutait tout particularisme et cherchait d'avancer le collectivisme sous toutes ses formes. ... L'analyse ne lui servait que d'action préparatoire pour la synthèse et la synthèse finale c'était pour lui l'idée mondiale.» ${ }^{3}$ Otlet was not content with abstract ideas. He toiled unceasingly for the realization of his dreams in tangible form, for the creation of an international center which should include documents covering the whole range of human activity-a vast library linked with an active information service. $\mathrm{He}$ realized, however, that such a service, and it was a service and not a mere depository that he was seeking to promote, presupposed a system by which the individual components of knowledge could be identified and selected from the integrated whole, and a "universal classification" had therefore to be devised for the use of scholars of all nations who would use the center. «La base de l'oeuvre projectée serait donc la classification de la totalité des choses, la classification universelle. Cette classification serait la clef d'or

\footnotetext{
3 Duyvis, F. D. "Paul Otlet." F.I.D. Communications, $12: 17,1945$.
} 
cachée dans l'arbre de la connaisance et ouvrant la porte au vaste trésor de la pensée humaine.» ${ }^{4}$

The space devoted to the faith of the Belgian pioneers is necessary if one is to appreciate rightly the contributions made by Dr. S. C. Bradford, Professor A. F. C. Pollard and Ernest Lancaster-Jones to problems of organizing materials in British libraries. Though British and European attitudes to documentation now show distinctive characteristics, they stem from a common source-the zeal of the founders of the Institut International de Bibliographie (now the Fédération Internationale de Documentation), the Reportorium Bibliographicum Universel, and the Universal Decimal Classification (U.D.C.).

This last was the name given to the "Brussels expansion" of the Decimal Classification and Relative Index of Melvil Dewey. In their search for a "universal" classification to be used by the many different countries cooperating in the supply of references to be fed into the center, Otlet and La Fontaine heard of the Dewey system, then unknown in Europe. A copy was received by them six weeks before the opening of the first International Bibliographical Conference in 1895 , and in this short time Otlet and La Fontaine reclassified the 400,000 cards they had already collected, in order to demonstrate the value of the classification to members of the conference.

\section{Bradford}

Of the trio with which this article is concerned Bradford was the first to come under the influence of the Belgian pioneers. He was so impressed by the potential value of the U.D.C. that, to quote his own words, "in 1900 , as a junior of some 18 months' experience" after joining the staff of the Science Museum, South Kensington, London, he had "the impudence to propose to

\footnotetext{
${ }^{4}$ Ibid.
}

use the Universal Decimal Classification for the Library subject-catalogue." ${ }^{5} \mathrm{His}$ suggestion was turned down, but for the rest of his life he was a determined apostle of the U.D.C. It was the mainspring of most of his written contributions to bibliography. For Bradford, documentation and the U.D.C. were synonymous.

Pollard's contacts with the U.D.C. seem to have begun a little later when, hearing of the work of the Institut International de Bibliographie, he visited Otlet and La Fontaine at Brussels in 1908 . Thereafter he too became one of the champions of the "universal classification" though, like Bradford, with little success at first. The English mind is unsympathetic toward universalism, and Otlet's ideas, both in Britain and on the continent, were sneered at as grandiose and impractical. Nevertheless the seed was being sown and even in Britain there were some important successes, notably Pollard's achievement in persuading the Optical Society to adopt the classification. Pollard's introductory chapters to the book, ${ }^{6}$ published by the society in 1926 as a guide to the decimal index of the Transactions of the Optical Society, still stand as one of the most lucid descriptions of the U.D.C.

By a coincidence of great importance for the future of documentation in Great Britain, the paths of Bradford and Pollard crossed in 1925 when Bradford, newly created deputy keeper of the Science Museum Library, came into contact with Pollard, then professor of optical engineering and instrument design at the Imperial College of Science. The two ardent champions of the U.D.C. joined forces and in

\footnotetext{
5 Bradford, S. C. "Minutes of the 17 th Annual General Meeting." Proceedings of the B.S.I.B., 6:117, 1945, Part 6.

Pollard, A. F. C. The Decimal Classification of the Institut International de Bibliographie. Partly Translated for the Formation and Use of $a$ Universal Bibliographical Repertory Concerning Optics, Light and Cognate Subjects. Cambridge, Cambridge University Press, 1926, p. 109.
} 
1927 formed the British Society for International Bibliography with Pollard as first president. To them was soon added Ernest Lancaster-Jones, assistant keeper in the Science Museum. He took on the work of honorary secretary of the society in 1929 , an office which he held until he was made keeper, i.e. chief librarian, at the Science Museum Library in 1938 in succession to Bradford when the latter retired. He thus directly inherited the tradition which had been built up by Bradford and which he maintained through the difficult war years until his untimely death in 1945 .

From the first the new society had strong links with the European documentation movement, and acted as the British Committee of the Institut International de Documentation, which the Institut International de Bibliographie had by then become. Indeed Pollard was president of the Institut from 1927 to 1931 and the society acted as "host" for the international conferences of the I.I.D. in Great Britain in 1929 and 1938 . It was very quickly realized that no real headway for the U.D.C. could be made in Great Britain until it could be made available in English, and in 1930 an English translation was sponsored by a joint committee of the British Society for International Bibliography (B.S.I.B.) and the Association of Special Libraries and Information Bureau (A.S.L.I.B.). The task of the publication of the English edition was subsequently taken over by the British Standards Institution but both Pollard and Bradford retained the closest touch with the editing. It was on this account that Bradford was a member of the International Commission of the U.D.C. and its chairman at the 1946 meetings in Paris and at the 1947 gathering in Berne.

The B.S.I.B., apart from being the British Committee of the Institut International de Documentation, was also a center of British documentation in its own right. The work of the three leaders, though owing much to continental inspiration in the first place, developed original characteristics. All three were scientists by training: Bradford was a chemist with particular interests in colloid chemistry, Pollard was a distinguished physicist with early experience of medicine and aeronautics, and LancasterJones was a mathematician who had received recognition as an expert in applied geophysics. None of them had received professional training as librarians and their interest in bibliography was practical, not academic. As practicing scientists they knew the waste and duplication which could arise through overlooked references. They saw bibliography as a tool and not as an end in itself.

Belief in the efficacy of the U.D.C. as a tool was a bond of union between Bradford and Pollard in the days of their early collaboration. "The Inadequacy of the Alphabetical Subject Index" Subject Indexes to Periodical Volumes"s were joint papers given at the A.S.L.I.B. conferences in 1930 and 1932 respectively. The U.D.C. continued to be Bradford's main theme in many papers published in the Proceedings of the British Society for International Bibliography, started by him in 1939. "For and Against the Decimal Classification," "The Universal Decimal Classification: Its Origin, and Purpose, Structure and Use" 10 and "Some General Principles of a Bibliographical Classification Scheme, with Application to the Uni-

\footnotetext{
"Pollard, A. F. C., and Bradford, S. C. "The Inadequacy of the Alphabetical Subject Index." Report of Proceedings of the Seventh Conference (of Aslib). 1930, p. 39*49.

Bradford, S. C., and Pollard, A. F. C. "Systematic Subject Indexes to Periodical Volumes," Report of Proceedings of the Ninth Conference (of Aslib). 1932, p. 20-30.

${ }^{2}$ Bradford, S. C. "For and Against the Decimal Classification." "Proceedings of the B.S.I.B. 4:76-90,

${ }_{10}^{1042}$ Bradford, S. C. "The Universal Decimal Classification: Tts Origin and Purpose, Structure and Use." Proceedings of the B.S.I.B., 6:21-36, 1944. Part 1.
} 
versal Decimal Classification"11 are characteristic. Nevertheless his other contributions to British documentation should not be forgotten, particularly that which has come to be known as "Bradford's law of scattering." Early in 1930 he investigated the degree to which articles on specific subjects are scattered throughout journals which are not primarily concerned with the subject in question. The Science Museum Library offered a field for experiment and the resulting formula was first published in $\mathrm{En}$ gineering on Jan. 26, $19344^{12}$ This he elaborated at intervals, and his theory occupies a chapter in his book Documentation, ${ }^{13}$ published in 1948 a few weeks before his death. The theory received further attention in connection with investigations into the reading habits of scientists carried out for the Royal Society's Scientific Information Conference of 1948. Still more recently the mathematical formula has been confirmed in a paper by B. C. Vickery published in the Journal of Documentation. ${ }^{14}$

As keeper of the Science Museum Library, Bradford was in the full stream of British bibliographical activity. He was a member of the A.S.L.I.B. Council from I932-43 and again from 1946-48, and he took an active part in the A.S.L.I.B. conferences. He would have been a vice president of the new Aslib which was formed by the amalagamation of A.S.L.I.B. and the B.S.I.B. He also contributed a paper $^{15}$ to the Royal Society's Empire Scientific Conference in 1946. All this was in addition to his constant work with the Fédération Internationale de Documentation.

${ }^{11}$ Bradford, S. C. "Some General Principles of a Bibliographical Classification Scheme, with Application to the Universal Decimal Classification." Proceedings of the B.S.I.B.. 6:57-69, rg44, Part 3.

${ }_{12}$ Bradford, "S. C. "Sources of Information on Specific Subjects." Engineering, p. 85, Jan. 26, 1934. ${ }_{13}$ Bradford, S. C. Documentation. London, Crosby Lockwood \& Son, Ltd., 1948, p. 156.

"Vickery, B. C. "Bradford's Law of Scattering." Journal of Documentation, 4:198-203, December 1948 .

${ }_{15}$ Bradford, S. C. "Complete Documentation." Re. port of the Royal Society Empire Scientific Conference, $1: 729 \cdot 38$, 1946 .

\section{Pollard}

Pollard, as has already been shown, was an enthusiast for the U.D.C. because, like Otlet, he saw in it the key to unlock the world's storehouse of information. To the end he remained one of the chief British experts in its use and a faithful advocate of its value. Nevertheless his duties as a professor in the University of London and his work as a research scientist left him less time to devote to bibliographical interests than was the case with Bradford. From I938 onward Pollard's contributions to the literature of documentation are chiefly in the form of presidential addresses to the B.S.I.B. During this period he was less concerned with the U.D.C. as such than with the development of his scheme for the "mobilization of knowledge" through an elaborate network of national and international abstracting and indexing bureaus. This idea had been put forward by him in a letter to the Times as early as 1919, but received detailed treatment in such papers as "The Mobilization of Knowledge and the 'Permanent World Encyclopaedia' of Mr. H. G. Wells" ${ }^{16}$ and "A Proposed Plan for the Mobilization of Bibliographical References to the Contents of the World's Non-Fiction Literature." ${ }_{17}$ This last paper was put forward by him again at the Royal Society's Scientific Information Conference in June 1948, a few weeks before his death. Pollard's modification of Otlet's plan was in line with general British reactions toward proposals for vast central information services. In 1926 J. G. Pearce, then chairman of the council of A.S.L.I.B., made the following remarks at the third annual conference of that

\footnotetext{
16 Pollard, A. F. C. "The Mobilization of Knowledge and the 'Permanent World Encyclopaedia' of Mr. H. G. Wells." Transactions of the I4th Conference of the International Federation for Documentation, 2 ; Cr6r-67, 1938 .

"A Proposed Plan for the Mobilization of Bibliographical References to the Contents of the World's Non-Fiction Literature." Proceedings of the B.S.I.B., 5:55-73, 1943, Part 3 .
} 
organization: "There are two main objections in English eyes to all completely centralized international schemes of the Brussels type. In the first place the cost both for capital expenditure and running expenses is enormous; in the second place there is a strong feeling that centralization on a large scale defeats the object in view, which is ready availability of material to the inquirer."18 However much Pollard may have admired Otlet and his idea for the Palais Mondiale it was becoming clear that the First World War had fatally undermined the atmosphere of confidence in the free exchange of information between scientists which was a prerequisite for the success of a comprehensive central service. The Second World War, though it increased the need for the organization of information, made it still clearer that each nation claimed to control the flow of any information considered important from the security point of view. Pollard envisaged a scheme which, since the exchange of information could be controlled at source, would be more practical in modern conditions. The scheme, in its original form, would have been very expensive and postwar conditions make its early realization unlikely.

\section{Lancaster-Jones}

Lancaster-Jones belonged to a later generation and he was therefore less closely affected by the early phases of the OtletLa Fontaine fervor. His transference from the Science Museum to the Science Museum Library in 1928 brought him into direct contact with Bradford and, inevitably, linked him with the activities of the B.S.I.B. of which he became vice president in 1945 , the year when Bradford succeeded Pollard as president. He took a full part in inter-

\footnotetext{
18 Pearce, T. G. "A National Intelligence Service."
} Report of the Proceedings of the Third Conference (of Aslib). 1926, p. 118-21. national bibliographical meetings, both of the Fédération Internationale de Documentation and of the Fédération Internationale des Associations Bibliothécaires and, in particular, he was responsible for the reports of the F.I.A.B. subcommittee on special libraries and information centers which were published in the Actes du Comité International des Bibliothèques from 1936 to 1939.

$\mathrm{He}$ became an expert in the use of the U.D.C. and took a considerable part in the editing of the English edition. His first bibliographical paper was on "The Decimal Classification in England," 19 prepared for the Congresso Mondiale delle Bibliotecha e di Bibliografia in Rome in 1929. He was a member of the A.S.L.I.B. Council from I $937-45$ and its treasurer from 1942 until his death.

Lancaster-Jones' approach to bibliography was strongly influenced by the mathematical trend of his intellect. He made valuable statistical investigations into the number of scientific papers published, the number of abstracts made of different papers, etc., the results of which provided the data from which Bradford deduced his law of scattering and were reflected in his own papers such as "Evaluation of Scientific and Technical Periodicals," ${ }^{20}$ or "Searching the Literature of Science." The technique of the administration of a special library appealed to his essentially practical nature and he was very much alive to the importance of such auxiliary aids as microfilm and other forms of document reproduction. In connection with the Fourteenth International Conference on Documentation held at London and Oxford in 1938, he organized an exhibition of micro-

\footnotetext{
${ }^{19}$ Lancaster-Jones, E. "The Decimal Classification in England." Atti del lmo Congresso Mondiale delle Bibliotecha e di Bibliografia, vol. 2.

${ }_{20}$ Lancaster-Jones, E. "Evaluation of Scientific and Technical Periodicals." Report of Proceedings of the Fifteenth Conference (of Aslib). 1938, p. 72-81.

${ }_{21}$ Lancaster-Jones, E. "Searching the Literature of Science." Journal of Scientific Instruments, 17:253-57, 1940.
} 
film readers at the Science Museum. His position as keeper of the Science Museum Library during the war brought him into close contact with the Aslib Microfilm Service to which he acted as treasurer and unofficial adviser. "Microfilm in Libraries" 22 and "The Operation of a Microfilm Service" ${ }^{23}$ show his interest in this subject. The responsibilities of keeping the Science $\mathrm{Mu}$ seum Library functioning as a live center of information during the war absorbed more and more of his energy and the list of his published papers on bibliographical subjects is not long. By his premature death in 1945 British documentation undoubtedly had a great loss.

The measure of the contribution made by these three men to the understanding of problems of organizing information services in libraries can best be assessed if we compare the general expectation of what a library service should provide in 1900 and in 1949. The library is no longer a depository, but is now a recognized center for the

${ }^{22}$ Lancaster-Jones, E. "Microfilm in Libraries." Report of Proceedings of the Seventeenth Conference (of Aslib). 1942, p. 34:37.

${ }^{23}$ Lancaster-Jones, E. "The Operation of a Microfilm Service." Proceedings of the B.S.I.B., 5:1-6, 1943, Part I. active provision of information. The processing of scientific data so that it may be accessible to the widest possible circle in industry and research is now the responsibility of governments, and the search for efficient schemes of classification is a matter of interest far beyond the ranks of the professional librarian. All these changes have taken place in the last 50 years. The generation of the pioneers is passing but as we close the chapter which records the achievements of such men as J. G. Priestley, the physiologist, editor of Physiological $A b$ stracts and secretary of the International Secretariat for Physiology of the Commission of the U.D.C., Leonard C. Wharton, the British Museum expert on Slavonic studies and problems of transliteration, William Macnab and W. P. Dreaper, chemical engineers and collaborators in the foundation of the Central Agricultural and Scientific Bibliography, all late members of the B.S.I.B., we pay special tribute to the exertions and undaunted perseverance of the three outstanding figures in that companySamuel Clement Bradford, Alan Faraday Campbell Pollard and Ernest LancasterJones. 